\title{
Effects of nitrogen on bionomics and food consumption of Cabera pusaria (Lepidoptera: Geometridae)
}

\author{
Emanuel Kula, Alena Pešlová, Petr Martinek \& Pavel Mazal
}

\begin{abstract}
Kula, E., Pešlová, A., Martinek, P. \& Mazal, P. 2014: Effects of nitrogen on bionomics and food consumption of Cabera pusaria (Lepidoptera: Geometridae). — Entomol. Fennica 25: 6-15.

Birches, Betula pendula Roth, grown in pots were fertilized with ammonium nitrate $\left(\mathrm{NH}_{4} \mathrm{NO}_{3}\right)$ in the amounts of $0 \mathrm{~g}, 0.5 \mathrm{~g}, 1 \mathrm{~g}$ and $1.5 \mathrm{~g}$ per plant four times per season on moist soil surface with subsequent gradual dissolution by watering. Cabera pusaria caterpillars from laboratory were fed on leaves with different

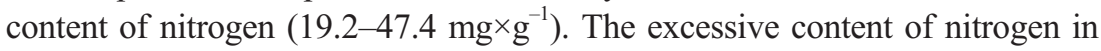
food appeared to be a stress factor as it increased mortality and development time of the caterpillars, decreased food consumption and weight of larvae and pupae, and caused anomalies at pupation. This is as expected for a summer-feeding caterpillar feeding on foliage with seasonally decreasing concentration of nitrogen.

E. Kula, A. Pešlová, P. Martinek \& P. Mazal, Faculty of Forestry and Wood Technology, Mendel University in Brno, Zemédělská 3, 61300 Brno, Czech Republic; E-mails: kula@mendelu.cz, alenapeslova@seznam.cz, martinekpe@ seznam.cz,mazal@mendelu.cz
\end{abstract}

Received 12 July 2012, accepted 24 June 2013

\section{Introduction}

White (1993) and Douglas (1993) presented nitrogen to be the limiting factor for insects. Nitrogen input into plants is associated with nitrogen oxides $\left(\mathrm{NO}_{\mathrm{x}}\right)$ pollution (Heliövaara \& Väisänen 1993) or with fertilization (Butler et al. 2012). The quality of food for phytophages is often positively affected by the increased concentration of organic nitrogen in leaves and phloem of plants (Rhoades 1979, White 1984, Mattson \& Haack 1987, Haddad et al. 2000). On the other hand, depending on species and conditions nitrogen fertiliser does not have only positive effects on insects (Bi et al. 2005, Pikul et al. 2005), but negative (Salmah et al. 1998, Pitan et al. 2000) or even no effects at all (Haile \& Hofsvang 2001, Srikanth et al. 2002). Sucking insects have shown a much stronger response to the level of nitrogen (fertiliser) than chewing insects (Annan et al. 1997, Megahed 2005, Schulz et al. 2008, Butler et al. 2012). Lepidoptera, Hemiptera and Diptera have shown a significant positive and Coleoptera a negative response to nitrogen fertiliser (Butler et al. 2012).

Some spring phytophages, for which the content of nitrogen in diet can be a limiting factor, are able to find plants or parts of plants rich in nitrogen (McNeil \& Southwood 1978). In these species, low doses of nitrogen provoke consumption of more food, prolonged feeding period and longer digestion and development. Inadequate $\mathrm{N}$ content in diet may be compensated by presence of symbiotic organisms in the digestive system, incidental carnivorousness etc. (Mattson 1980).

Preference of tissues with higher content of 
nitrogen in spring species was confirmed for example in Phyllobius sp. (Kaňová \& Kula 2004), Pristiphora abietina (Berger \& von Katzensteiner 1994), Choristoneura fumiferana (Shaw \& Little 1972) and Choristoneura conflictana (Bryant et al. 1987). Positive reaction of phytophages to increased $\mathrm{N}$ content in plant tissues may also be associated with the decrease of the phenolic compound content (Jones 1976, Kiraly 1976, Joseph et al. 1993).

For summer species (e.g. Bupalus piniarius, Neodiprion swainei) appearing at the time of natural decline of $\mathrm{N}$ content in needles, oversupply of N may be unfavourable (Smirnoff \& Bernier 1973, Katzel \& Loffler 1995). In this study, we use the geometrid Cabera pusaria as a model species with larvae feeding during summer period, i.e. on leaves with decreasing natural concentration of $\mathrm{N}$.

In air-polluted areas with a high proportion of birch in forest stands, C. pusaria is the most abundant species of the moths attracted to light traps in Sněžník (5047'57.01" N, 1405’04.74” E) (Děčín Highlands, Czech Republic) (Kula 2007). It is also the most represented species within the fauna of caterpillars in the birch crowns (Kula 2008). Generally, flight activities take place in mid-May to mid-September with culmination in the first half of July (Kula 2007).

Caterpillars of C. pusaria rank among disjoint oligophages occurring in crowns of birch trees in the Palaearctic region (Copolovici et al. 2011) from the beginning of June till the end of September. The period of caterpillar hatching is long, 46 weeks. Caterpillars go through five instars with the lengths of 2-4-8-12-17 $\mathrm{mm}$ (Gninenko 1974). They live individually above all in the late summer aspect when they create a dominant component of the birch crown fauna in the Děčín Highlands and Ore Mountains (Czech Republic), their presence till the end of the growing season being not a rarity (Kula 2008). They occur in broadleaved forests on poplar, willow, birch and alder but also on hornbeam or bird cherry (Ladenburger 1989). In Scandinavia, it is mentioned particularly on birch (Nordström et al. 1941). The species pupates in humus layer where it also overwinters.

Birch is an unpretentious light-demanding species tolerating only open crown canopy. It is not sensitive to late frosts and it grows well on poor dry soils as well as on acid sites ( $\mathrm{pH} 3.5-5.0)$ (Hejný \& Slavík 1990). Increased inputs of nitrogen with simultaneous drought stress cause intensive premature summer leaf-fall (Kaňová \& Kula 2004) and decreased increment (Kula et al. 2012a). Damage to forests by C. pusaria has not been reported (Kula 2007). Young, actively growing tissues show the highest concentration of nitrogen (e.g. in birches $30-70 \mathrm{mg} \times \mathrm{g}^{-1}$ ) and its decrease is connected with tissue aging (Rodin \& Bazilevich 1967, Mattson 1980, Hrdlička \& Kula 2001). Throughout the growing season, a wide spectrum of phytophagous species develop on the leaves (Kula 2008), with species composition limited by adaptation to obtaining necessary energy and nutrition, surpassing the defensive reactions of the plant and to other environmental factors (Mattson 1980).

The increased content of nitrogen in the diet of $C$. pusaria caterpillars that in natural conditions develop during summer period on birch leaves with decreasing $\mathrm{N}$ content may have a negative impact on their development, food consumption and mortality. Accordingly, the aim of this paper is to describe the response of C. pusaria caterpillars to the increased level of nitrogen in birch leaves (Betula pendula).

\section{Material and methods}

Birches were grown from one year old seedlings in $10 \mathrm{~L}$ pots in a forest nursery (Brno Rečkovice, altitude $220 \mathrm{~m}$ a.s.1.) with soil substrate from the Cambic mineral horizon of a forest soil (Kula et al. 2012a). Changes in the content of nitrogen in the substrate were induced by application of ammonium nitrate $\left(\mathrm{NH}_{4} \mathrm{NO}_{3}\right)$ to the plants in four treatments: $0 \mathrm{~g}$ (T0), $0.5 \mathrm{~g}$ (T1), $1 \mathrm{~g}$ (T2) and $1.5 \mathrm{~g}$ (T3). Fertilization was carried out in one month intervals, four times in the year of planting (2006) and five times in 2007 and 2008. The amount of ammonium nitrate applied to a plant was chosen in order to achieve a gradient of $\mathrm{N}$ content in the birch leaves ranging from insufficiency to oversupply. The normal concentration of nitrogen in birch leaves according to Bergmann (1988) is $2.5-4 \%$.

In accordance with the methods of ICP Fo- 
rests (International Co-operative Programme on Assessment and Monitoring of Air Pollution Effects on Forests operating under the UNECE Convention on Long-range Transboundary Air Pollution), mature leaves (except the four terminal ones) were collected from the upper half of the birch crown annually at the turn of August and September and the content of nitrogen was determined after desiccation at $70{ }^{\circ} \mathrm{C}$ for 24 hours by the method of Kjeldahl using the Tecator 2300 Kjeltec Analyzer Unit.

Kula et al. (2012a) showed that in birches with similar treatments as in this study there were statistically significant differences in the content of nitrogen in leaves between the treatments $\mathrm{T} 0$ $\mathrm{T} 3$ at the end of growing season, i.e. that the fertilization was effective. Accordingly, similar differences among treatments are assumed in this study, too.

Laboratory rearing of $C$. pusaria (30 females and 20 males) caught in the Ore Mountains was established in mid-July 2008. When the caterpillars began to hatch from the laid eggs (22 July), the caterpillar rearing on foliage from treatments T0-T3 in Petri dishes began. In each of the dishes (15 repetitions in each treatment), 10 caterpillars of the $1^{\text {st }}$ instar were placed (total of 600 caterpillars). The rearing was conducted under controlled conditions of the Climacell 707 thermostat with a simulation of the following daily exposure:

- Daylight $10 \mathrm{~h}$, temperature $19.8^{\circ} \mathrm{C}$, relative humidity $60 \%$

- Without light $6 \mathrm{~h}$, temperature $15^{\circ} \mathrm{C}$, relative humidity $85 \%$

- Transitional light with $20 \%$ intensity twice for $4 \mathrm{~h}$ with gradual changes of temperature and humidity.

Branches with leaves from several host plants grown in plastic greenhouses under different treatments (T0-T3) were cut in each check-up day and transported to the laboratory in coolers within an hour. The long shoot branches were cut up to short segments (1-2 cm long) with only one mature leaf left. The segments were moistened and then placed into Petri dishes with caterpillars of the corresponding treatments (T0-T3). The interval of food (new leaves) exchange was $48 \mathrm{~h}$. During the food exchange, the instar of each cat- erpillar was determined, as well as the date of pupating and weight of the pupa. Moreover, mortality of caterpillars was monitored for the particular treatments and evaluated in 10-day intervals.

The consumed leaf area was determined as a difference between the leaf area before and after the experiment using a Leaf Area Meter AM300 (ADC BioScientific, Hoddesdon, England). The area of the leaves with only minor feeding marks by the $1^{\text {st }}$ instar caterpillars, which could not be detected by this apparatus, was determined in the biometric laboratory of the Faculty of Forestry and Wood Technology, MENDELU in Brno by means of the system of analysis and processing the NIS - Elements AR image (digital camera 5 Mpix Nikon DS - Fi 1 with macro-objective Navitar, exposure KAISER RB 5000 DL, exciter lamp KAISER Prolite Basic, computer with NIS - Elements AR program, version 2.30, processor X86, 2533 MHz, HD 230 GB, RAM 2 MB). The output of measurements mentioned above was the mean consumed areas of the leaves per one caterpillar in a Petri dish by each check-up day. Food consumption was evaluated in 10-day intervals.

After termination of the caterpillar rearing, the content of $\mathrm{N}$ in mixed samples of birch leaves remains was assessed in 14-day intervals in order to determine the change of $\mathrm{N}$ content in the individual treatments T0-T3.

Statistica.cz (StatSoft 2007) software was used to analyse the data. Shapiro-Wilks test revealed that most of the data obtained in C. pusaria rearing (length of development, weight of larvae and pupae and food consumption) deviated from the normal distribution. Therefore, the non-parametric Kruskal-Wallis ANOVA (K-W test hereafter) was used. Subsequently we performed the Dunn's multiple comparison test. The distribution of the data did not deviate from normal only for the length of $5^{\text {th }}$ instar caterpillars' development and the mortality of the $1^{\text {st }}$ instar caterpillars. ANOVA with Fisher's multiple comparison (LSD test) was used for these data.

For the variables with measured traits for each individual caterpillar, the averages of the values of all caterpillars reared in each Petri dish were used in statistical tests, i.e. the Petri dishes represented independent replicates within treatments, not the individual caterpillars. 


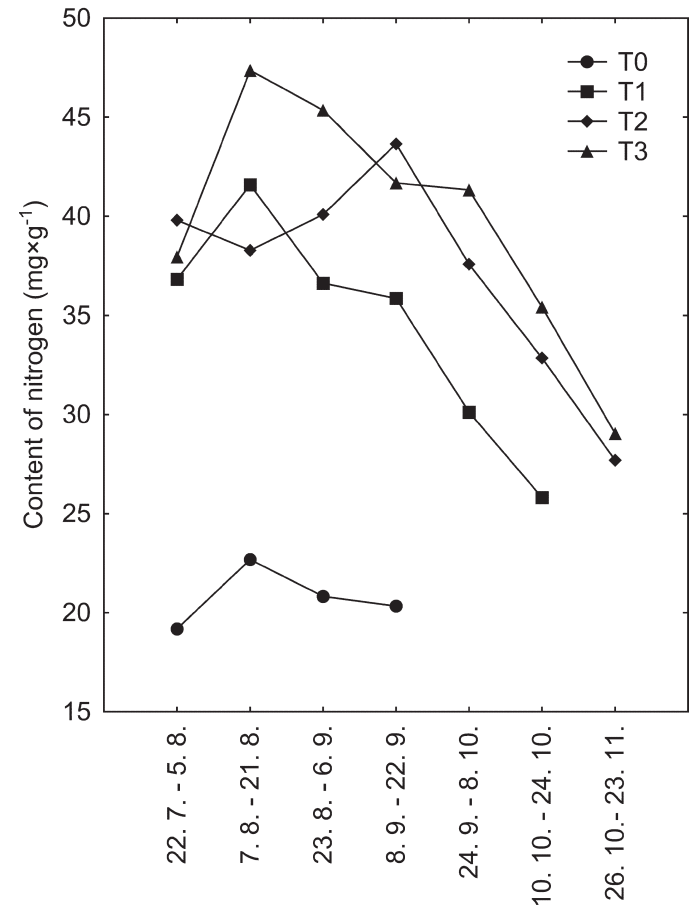

Fig. 1. Average content of nitrogen in leaves of Betula pendula fed to Cabera pusaria caterpillars in treatments T0-T3 (application of $\mathrm{NH}_{4} \mathrm{NO}_{3}$ as: T0, $0 \mathrm{~g}$; T1, $0.5 \mathrm{~g}$; T2, $1 \mathrm{~g}$; T3, $1.5 \mathrm{~g}$ ). For T0, caterpillars had pupated by $5^{\text {th }}$ period.

\section{Results}

\subsection{Content of nitrogen in remains of birch leaves after $C$. pusaria caterpillar rearing}

The level of nitrogen in leaves of the control birch trees (T0) was markedly lower compared to the leaves from the fertilized treatments T1-T3 (Fig. 1). From 22 September onwards the gradual decline of nitrogen in leaves due to senescence became evident in treatments $\mathrm{T} 1-\mathrm{T} 3$. In treatment T0, the caterpillars had already pupated by this date and, therefore, there were no leaf remains to be analysed for the content of nitrogen.

\subsection{Caterpillar mortality}

Mortality (\%) of C. pusaria caterpillars at the end of the rearing period was assessed separately for each Petri dish, originally containing 10 individuals. The same procedure was chosen to determine

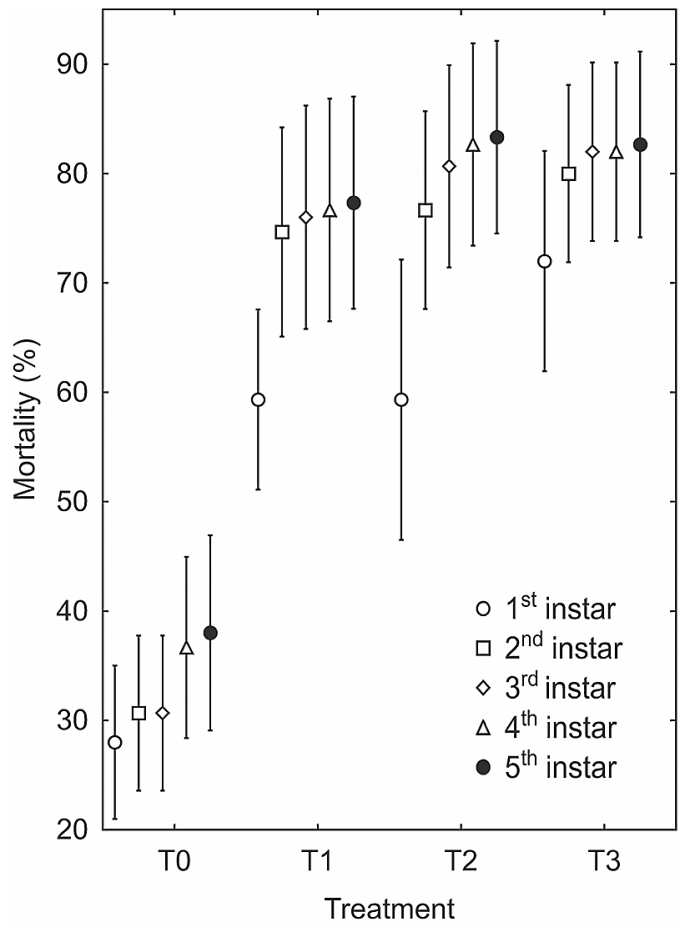

Fig. 2. Means ( $\pm 0.95 \%$ confidence intervals) of mortality in Cabera pusaria caterpillars $\left(1^{\text {st }}-5^{\text {th }}\right.$ instars and total) reared on Betula pendula leaves with increased content of nitrogen, see Fig. 1.

mortality of each instar with the cumulative rise of the dead individuals. Therefore, the mortality in the $5^{\text {th }}$ instar equals the mortality assessed for the whole development.

There were significant differences in mortality among the treatments in the first instar (ANOVA, $F(3,56)=16.914, p<0.001$ ) as well as in other instars (in all K-W tests, $H(3, N=60)$ $>30.923, p<0.001)$. The first instar was the most sensitive with the highest frequency of mortality in all treatments (T0-T3). Additional nitrogen in diet (treatments T1-T3) turned out to be the key factor in $1^{\text {st }}$ instar mortality $(59.3-71.0 \%)$ compared to the control $(28.0 \%)$ (Fig. 2, significant differences between T0 and T1-T3, LSD tests: $p<0.001$, no significant differences among T1T3, LSD tests: $p>0.054$ ).

During the $2^{\text {nd }}-5^{\text {th }}$ instars, there were significant differences between $\mathrm{T} 0$ and other treatments like in $1^{\text {st }}$ instar (Dunn's tests: $p<0.001$ ), but no differences among treatments T1-T3 (Dunn's tests: $p>0.999$ ). In the $2^{\text {nd }}$ and $3^{\text {rd }}$ instars, the inten- 

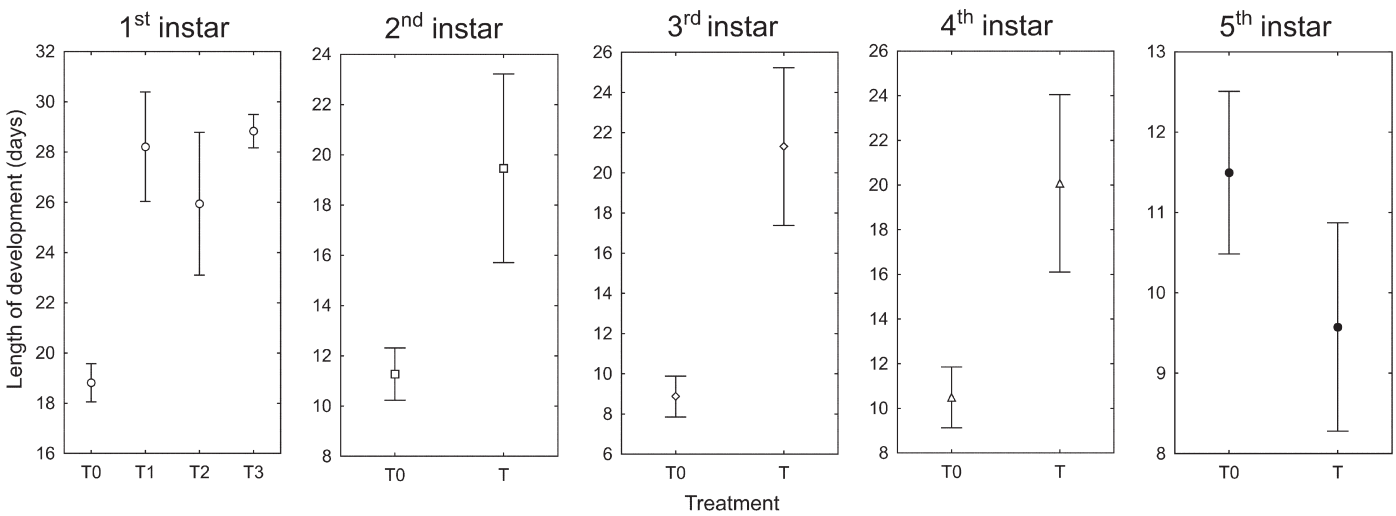

Fig. 3. Means ( $\pm 0.95 \%$ confidence intervals) of length of developmental period of each instar of Cabera pusaria caterpillars. Treatments T0-T3, see Fig. 1.

sity of mortality decreased and in the $4^{\text {th }}$ and $5^{\text {th }}$ instars it was minimal in comparison to mortality in the first instar (Fig. 2). In T0, totally $38.0 \%$ of the caterpillars did not finish their development while in the treatments with supplemented nitrogen (T1-T3), mortality reached $77.3-83.3 \%$ (Fig. 2).

\subsection{Length of development of caterpillars}

Due to high mortality, development of C. pusaria caterpillars during the rearing was assessed separately for each instar.

There were significant differences in the duration of the $1^{\text {st }}$ instar among the treatments $(\mathrm{K}-\mathrm{W}$ test $H(3, N=54)=30.302, p<0.001)$, with T0 statistically significantly different (shorter development, Fig. 3) from T1-T3 (Dunn's tests, $p<0.005$ ), but no significant differences among T1, T2 and T3 (Dunn's tests, $p>0.925$ ).

Due to the limited number of caterpillars (high mortality) in the nitrogen-affected treatments (T1-T3) we decided to merge them together from the $2^{\text {nd }}$ instar onwards into a single nitrogen treatment $(\mathrm{T})$. For the $2^{\text {nd }}-5^{\text {th }}$ instars, statistically significant differences between the control (T0) and the individuals reared on nitrogen-enriched food $(\mathrm{T})$ were found $\left(2^{\text {nd }}\right.$ instar, $\mathrm{K}-\mathrm{W}$ test: $H(1, N=36)=14.607, p<0.001 ; 3^{\text {rd }}$ instar, K-W test: $H(1, N=28)=18.368, p<0.001 ; 4^{\text {th }}$ instar, KW test: $H(1, N=26)=17.898, p<0.001 ; 5^{\text {th }}$ instar, ANOVA: $F(1,24)=6.686, p<0.021)$. The average lengths of the individual instars are shown in Fig. 3.

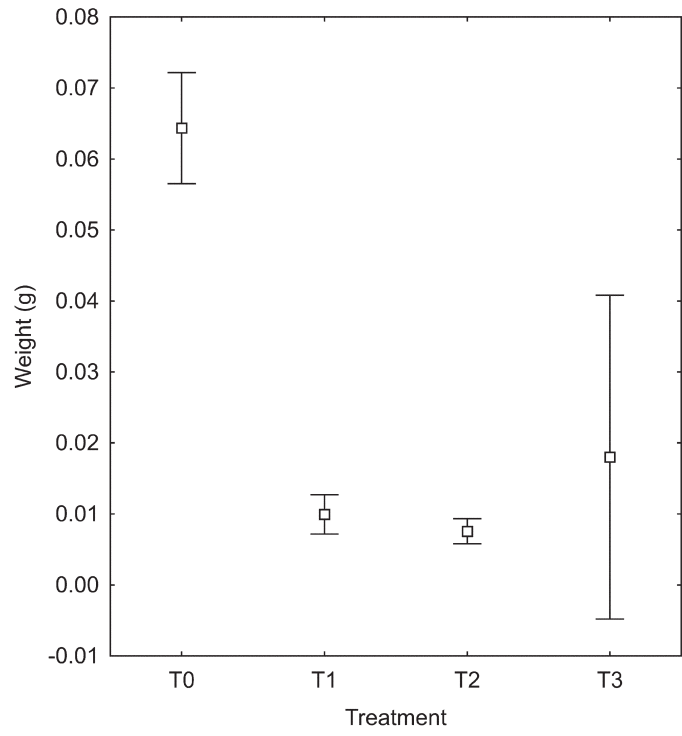

Fig. 4. Means ( $\pm 0.95 \%$ confidence intervals) of weight of caterpillars of Cabera pusaria after 52 days from the experiment establishment. Treatments T0-T3. see Fig. 1.

\subsection{Weight of caterpillars and pupae}

After 52 days from the begin of the experiment, the weight of every live larva was determined. There were significant differences in weights of caterpillars among the treatments $(\mathrm{K}-\mathrm{W}$ test: $H(3$, $N=107)=72.372, p<0.001)$. Weight of the caterpillars in control (T0) was significantly higher than that in the treatments with additional nitrogen (T1-T3) (Fig. 4) (Dunn's tests: $p<0.001$ ). 


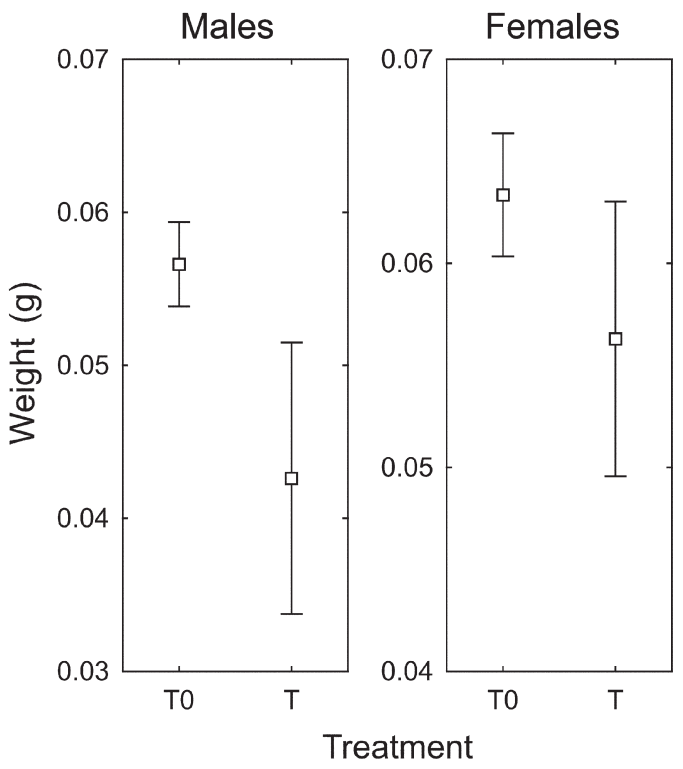

Fig. 5. Means ( $\pm 0.95 \%$ confidence intervals) of weight of pupae of males and females of Cabera pusaria. Treatments T0 and T ( $\mathrm{T}=\mathrm{T} 1, \mathrm{~T} 2, \mathrm{~T} 3$ combined), see Fig. 1.

Between the treatments T1-T3, statistically significant differences did not occur (Dunn's tests: $p>0.999$ ) (Fig. 4).

The number of pupae obtained in treatments T1-T3 was limited not only by high mortality of the caterpillars, but also by mortalities and abnormalities that occurred during the pupation (41\% of the pupae in treatments $\mathrm{T} 1-\mathrm{T} 3$ were deformed). Only $4 \%$ of the caterpillars in the treatments T1-T3 completed successfully their development to the pupal stage. Therefore, the treatments with additional nitrogen had to be combined into one treatment $(\mathrm{T})$. Males and females were evaluated separately. The average weight of male $(0.053 \mathrm{~g})$ and female $(0.062 \mathrm{~g})$ pupae differed significantly (K-W test: $H(1, N=69)$ $=14.749, p<0.001)$. Only in male pupae a statistically significant difference was found between the control T0 and treatment T (K-W test: $H(1$, $N=31)=8.511, p<0.004$ ) (Fig. 5). In also female pupae a trend of weight decrease with the increased nitrogen concentrations was noted (Fig. 5) but not quite a statistically significant difference between the treatments $\mathrm{T} 0$ and $\mathrm{T}$ was found due to the somewhat higher dispersion $(\mathrm{K}-\mathrm{W}$ test: $H(1, N=38)=3.581, p=0.058)$.

\subsection{Food consumption}

The different rate of the caterpillar development allowed us to evaluate the differences in the consumption of food between the particular treatments for the first 60 days of rearing (until 20.IX.2008). By this time, most of the caterpillars in the treatment T0 had pupated, hence the statistical group needed for the comparison was not available any more. The average consumption of food by one caterpillar was evaluated in ten-day intervals (Fig. 6). During the first ten days (22.VII.-1.VIII.2008), statistically significant differences between the treatments were not observed (K-W test: $H(3, N=60)=5.971, p=0.113$ ) (max. consumption $1.58 \mathrm{mg}$ in $\mathrm{T} 0$ and $\mathrm{min} .1 .39$ $\mathrm{mg}$ in T3). During the following five periods of ten days, there were statistically significant differences among the treatments (in all K-W tests: $H(3, N=(27-59)>19.876, p<0.001)$. In the con-

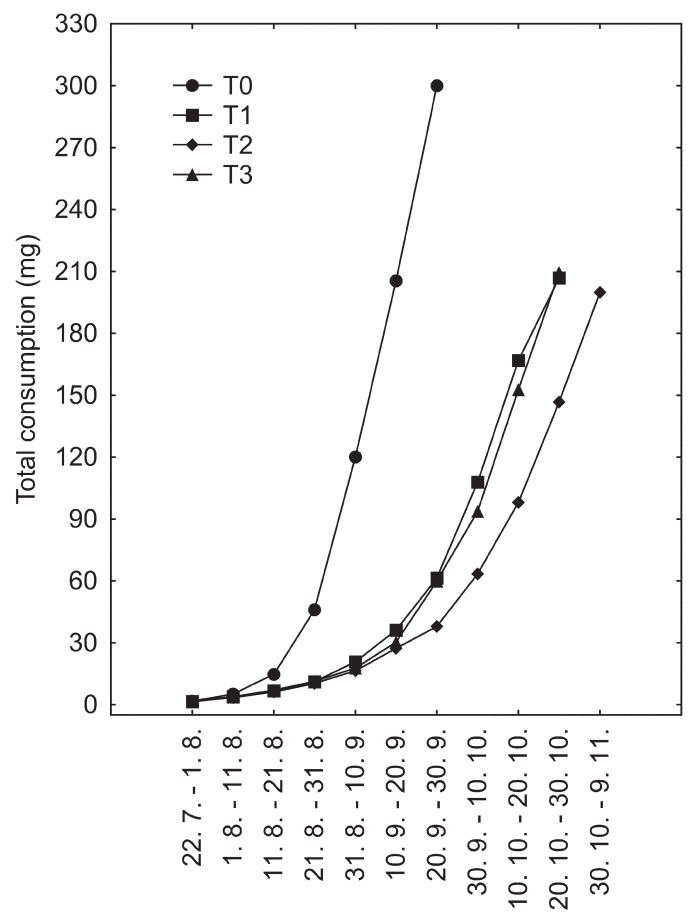

Fig. 6. Cumulative curve of the total consumption of food by caterpillars of Cabera pusaria converted per one caterpillar in laboratory rearing with additional nitrogen in food (Betula pendula). Treatments T0-T3, see Fig. 1. 
trol treatment, feeding gradually increased from $3.36 \mathrm{mg}$ to $83.30 \mathrm{mg}$ while in treatments $\mathrm{T} 1-\mathrm{T} 3$ clearly a slower increase of food consumption was noted, being from $1.89 \mathrm{mg}$ to $18.27 \mathrm{mg}$. The differences between $\mathrm{T} 0$ and other treatments were statistically significant (Dunn's tests: $p<0.025$ ), except for the T0 vs. T1 comparison of the period from 31.8. to 10.9., which was not significant (Dunn test: $p>0.081$ ). During the whole larval period, the average consumption of food by a caterpillar in $\mathrm{T} 0$ reached $300 \mathrm{mg}$, whereas in treatments $\mathrm{T} 1-\mathrm{T} 3$ it remained close to $200 \mathrm{mg}$ (Fig. 6).

\section{Discussion}

The increased content of nitrogen in food had markedly negative effects on C. pusaria caterpillars. In the Ore Mountains, Hrdlička and Kula (2001) specified the average content of nitrogen in birch leaves in the growing season as 28.59 $\mathrm{mg} \times \mathrm{g}^{-1}$. Compared to the period 1995-1998 (Kula \& Hrdlička 1998) they stated that air-pollution inputs of nitrogen compounds were thus adequate for normal conditions and their effect receded in the area of the Ore Mountains. According to Hrdlička and Kula (2001), the level of nitrogen in birch leaves declined during the grow-

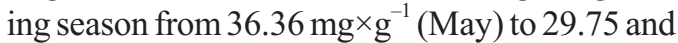

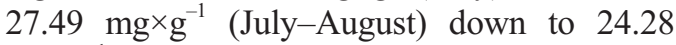
$\mathrm{mg} \times \mathrm{g}^{-1}$ (September). In the present study, caterpillars in the control treatment were reared on food with lower level of nitrogen (19.19-22.68 $\left.\mathrm{mg} \times \mathrm{g}^{-1}\right)$, whereas the treatments with additional nitrogen markedly exceeded the above-men-

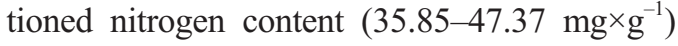
characterizing the area from where the parental moths for this study had been trapped. Thus, an environment with clearly differentiated food as nitrogen content was created.

Changes in the quality of food may represent a stress situation for phytophages, for example due to production of secondary metabolites by plants (Mattson 1980, White 1984, Bryant et al. 1993). Responses of phytophages to air pollution and increased inputs of nitrogen into plants has been discussed by, e.g., Jansson and Smilowitz (1985), Heliövaara and Väisänen (1993) and Pronos et al. (1999).
In the present study, the $1^{\text {st }}$ and $2^{\text {nd }}$ instar caterpillars of $C$. pusaria responded most sensitively to the high level of nitrogen in food. Mortality increased continuously through the $3^{\text {rd }}$ to the $5^{\text {th }}$ instar, being not different among treatments with increased $\mathrm{N}$ levels (T1-T3) at the end of larval development. The deviations from the control treatment showed that the higher contents of nitrogen increases caterpillar mortality and prolongs their development. An increase of mortality with the increased content of nitrogen in food was also observed in hymenopterous larvae of $\mathrm{NeO}$ diprion swainei (Smirnoff \& Bernier 1973), the feeding of which culminated in August and at the beginning of September (McLeod 1970). Despite their longer period of development, the caterpillars of $C$. pusaria fed with food with additional nitrogen consumed lower total amount of food than the caterpillars in the control treatment. The caterpillars in treatments with additional nitrogen reached also lower weight than those in control treatment in the comparable period. The same was true for the pupae of the caterpillars that completed their development, though for females this was not quite statistically significant. Moreover, contrary to the treatments with additional nitrogen, no developmental anomalies appeared in pupae of the control treatment. This fact can be related even to toxicity of nitrogen-rich food for larvae ordinarily developing on leaves in the period of naturally declining $\mathrm{N}$ content. On the other hand, many early season insect herbivores are known to react positively to increased concentrations of organic nitrogen in leaves and phloem of plants (White 1984, Haddad et al. 2000), for example Choristoneura fumiferana (Shaw \& Little 1972), Choristoneura conflictana (Bryant et al. 1987) and Lymantria dispar (Lindroth et al. 1991, 1997, Kula et al. 2012b, Pešlová 2012). Feeding of these phytophages occurs early in spring when the content of nitrogen in leaves is the highest (Rodin \& Bazilevich 1967, Hrdlička \& Kula 2001, Šrámek et al. 2009).

It is important to take into account the generally different responses of particular plant species, especially to stress, and subsequently the different responses of insects induced by changes in the quality of food (Larsson 1989). Therefore, it is not possible to generalize the detected responses of $C$. pusaria caterpillars. Other species 
or even the same insect species can behave differently on another plant species (Heliövaara \& Väisänen 1993). On pine (Pinus ponderosa), population density of phytophages decreased with increasing content of nitrogen but the species diversity remained the same (evaluated at the level of orders and suborders) (Jones \& Paine 2006), indicating that their development was possible even at the increased level of nitrogen, but it was accompanied by increased mortality. Opposite responses to higher inputs of nitrogen were shown in sucking insects; Psylloidea showed a fall of species diversity and increase of abundance (Prestidge 1982), and the plant lice Metopolophium dirhodum an increase of abundance (Honek 1991).

In summary, the hypothesis presuming negative responses of caterpillars of the summer phytophagous species C. pusaria to increased N content in their food (Betula pendula) was supported. Smaller size of caterpillars and especially male pupae (in the case of a female pupae we didn't find a statistically significant difference) and prolonged development of the larvae and their increased mortality were observed.

Acknowledgements. This research was carried out under projects funded by the grant for the project NAZV QH 82113 and VZ MSM 6215648902, and with the financial support of the regional joint stock companies and concerns: Netex Ltd. in Děčín, Nadace ČEZ Co. Prague, Lafarge cement Co. in Č́źžkovice.

\section{References}

Annan, I. B., Ampong-Nyarko, K., Tingey, W. M. \& Schaefers, G. A. 1997: Interactions fertilizer, cultivar selection, and infestation by cowpea aphid (Aphididae) on growth and yield of cowpeas. - International Journal of Pest Management 43: 307-312.

Berger, R. \& von Katzensteiner, K. 1994: Mass outbreak of the small spruce sawfly Pristiphora abietina (Christ) (Hym., Tenthredinidae) in Hausruck. 2: Influence of air pollution. - Journal of Applied Entomology $118(3)$ : 253-266.

Bergmann, W. 1988: Ernährungsstörungen bei Kulturpflanzen (Entstehung, visuelle und analytische Diagnose). - Wolkseigene Betrieb Gustav Fischer Verlag, Jena. $762 \mathrm{pp}$.

Bi, J. L., Lin, D. M., Lii, K. S. \& Toscano, N. C. 2005: Impact of cotton planting date and nitrogen fertilization on Bemisia argentifolii populations. - Insect Science 12: $31-36$.
Bryant, J. P., Clausen, T. P., Reichardt, P. B., McCarthy, M. C., Werner, R. A. \& Bryant, J. B. 1987: Effect of nitrogen fertilization upon the secondary chemistry and nutritional value of Quaking Aspen (Populus tremuloides Michx.) leaves for the Large Aspen Tortrix (Choristoneura conflictana (Walker)). — Oecologia 73: 513-517.

Bryant, J. P., Reichardt, P. B., Clausen, T. P. \& Werner, R. A. 1993: Effect of mineral nutrition on delayed inducible resistance in Alaska paper birch. - Ecology 74: 2072-2084.

Butler, J., Garratt, M. P. D. \& Leather, S. R. 2012: Fertilisers and insect herbivores: a meta-analysis. - Annals of Applied Biology 161: 223-233.

Copolovici, L., Kännaste, A., Remmel, T., Vislap, V. \& Niinemets, U. 2011: Volatile emissions from Alnus glutionosa induced by herbivory are quantitatively related to the extent of damage. - Journal of Chemical Ecology 37: 18-28.

Douglas, A. E. 1993: The nutritional quality of phloem sap utilized by natural aphid populations. - Ecological Entomology 18: 31-38.

Gninenko, Ju. I. 1974: Očagi massovogo razmnoženija listogryzujuščich nasekomych v berezovych lesach Zauralja. (Causes of outbreak of leaf-eating insect pests in birch forests of Zauralja.). — Ekologia 214: 98-101. [In Russian.]

Haddad, N. M., Haarstad, J. \& Tilman, D. 2000: The effects of long-term nitrogen loading on grassland insect communities. - Oecologia 124: 73-84.

Haile, A. \& Hofsvang, T. 2001: Effect of sowing dates and fertilizer on the severity of stem borer (Busseola fusca Fuller, Lepidoptera: Noctuidae) on sorghum in Eritrea. - International Journal of Pest Management 47: 259-264.

Hejný, S. \& Slavík, B. 1990: Květena České republiky 2. (Flora of the Czech Republic 2.) - Academia, Praha. 540 pp. [In Czech.]

Heliövaara, K. \& Väisänen, R. 1993: Insects and pollution. - The Chemical Rubber Company Press, Inc,. Boca Raton, Florida. 393 pp.

Honek, A. 1991: Nitrogen fertilization and abundance of the cereal aphids Metopolophium dirhodum and Sitobion avenae (Homoptera, Aphididae). — Zeitschrift für Pflanzenkrankheiten und Pflanzenschutz 98: 655660.

Hrdlička, P. \& Kula, E. 2001: Obsah prvků v listech břízy v transektu Litvínov v průběhu vegetačního období. (Content of elements in leaves of birch in the transect Litvínov during vegetation period.) — In: Sb. semináře „Výsledky a postupy výzkumu v imisní oblasti SV Krušnohoří", Phare program, Teplice 1. 3. 2001: 6368. [In Czech.]

Jansson, R. K. \& Smilowitz, Z. 1985: Influence of nitrogen on population parameters of potato insects: abundance, population growth and within-plant distribution of the green peach aphid, Myzus persicae (Homoptera: Aphididae). — Environmental Entomology 15: 4955.

Jones, F. G. W. 1976: Proceedings of the 12th Colloquium 
of the International Potash Institute, Izmir, Turkey, 1976: Potassium and plant health: 233-258.

Jones, M. E. \& Paine, T. D. 2006: Detecting changes in insect herbivore communities along a pollution gradient. - Environmental Pollution 143: 377-387.

Joseph, G., Kelsey, R. G., Moldenke, A. F., Miller, J. C., Berry, R. E. \& Wernz, J. G. 1993: Effects of nitrogen and douglas-fir allelochemicals on development of the gypsy moth, Lymantria dispar. - Journal of Chemical Ecology 19: 1245-1263.

Kaňová, D. \& Kula, E. 2004: The effect of stress factors on birch (Betula pendula Roth). — Journal of Forest Science 50: 399-404.

Katzel, R. \& Loffler, S. 1995: Ecophysiological investigations on the influence of nitrogen damaged pines on Bupalus piniarius and Dendrolimus pini (Lepidoptera). - Mitteilungen der Deutschen Gesellschaft fur Allgemeine und Angewandte Entomologie 10 (1-6): 63-65.

Kiraly, Z. 1976: Plant disease resistance as influenced by biochemical effects of nutrients in fertilizers. Fertilizer Use and Plant Health Proceedings of the 12th Colloquium of the International Potash Institute, Izmir, Turkey, 1976: 33-46

Kolomiec, N. G. \& Artamonov, C. D. 1985: Češujekrylye - vrediteli berezovych lesov. (Lepidoptera - pests of birch forests.) - Novosibirsk, Izdavatelstvo „Nauka", Sibirskoe otdelenie. 129 pp. [In Russian.]

Kula, E. 2007: Motýli porostů náhradních dřevin v imisním území Sněžníku. (Moths of stands of substitute species in the air-polluted area of Sněžník.) — Nakl. Lesnická práce, s.r.o. 107 pp. [In Czech.]

Kula, E. 2008: The seasonal population dynamics of moth larvae feeding in birch stands of the Krusne hory mountains (Czech Republic) from 1986-2004. - Ekológia (Bratislava) 27: 119-129.

Kula, E. \& Hrdlička, P. 1998: Monitoring živinových a cizorodých prvků $\mathrm{v}$ listech bříz rostoucích $\mathrm{v}$ imisní oblasti. (Monitoring of nutrient and extraneous elements in birch leaves growing in an air-polluted region.) — Lesnictví-Forestry 44: 1-9. [In Czech.]

Kula, E., Pešlová, A. \& Martinek, P. 2012a: Effects of nitrogen on growth properties and phenology of silver birch (Betula pendula Roth). — Journal of Forest Science 9: 391-399.

Kula, E., Pešlová, A., Martinek, P. \& Mazal, P. 2012b: Vliv dusíku na vývoj housenek a výběr hostitelské rostliny některými fytofágy. (Effects of nitrogen on the development of caterpillars and the selection of a host plant by some phytophages.) - Zprávy lesnického výzkumu 57: 327-336. [In Czech.]

Ladenburger, U. 1989: Vergleichende Untersuchungen zum Vorkommen phytophager Larvenstadien der Blattwespen (Hymenoptera, Tenthredinoidea) und der Schmetterlinge (Lepidoptera) an verschieden strukturierten Waldrändern in der Umgebung Freiburgs. Diplomarbeit, Institut für Biologie I (Zoologisches Institut), Albert-Ludwigs-Universität, Freiburg i. Br. $141 \mathrm{pp}$.

Larsson, S. 1989: Stressful times for the plant stress - in- sect performance hypothesis. - Oikos 56: 277-283.

Lindroth, R. L., Barman, M. A. \& Weisbrod, A. V. 1991:

Nutrient deficiencies and the gypsy moth, Lymantria dispar: Effects on larval performance and detoxication enzyme activities. - Journal of Insect Physiology 37 : $45-52$.

Lindroth, R. L., Klein, K. A., Hemming, J. D. C. \& Feuker, A. M. 1997: Variation in temperature and dietary nitrogen affect performance of the gypsy moth (Lymantria dispar L.). - Physiological Entomology 22: 5564.

Mattson, W. J. 1980: Herbivory in relation to plant nitrogen content. - Annual Review of Ecology, Evolution, and Systematics 11: 119-161.

Mattson, W. J. \& Haack, R. A. 1987: The role of drought in outbreaks of plant-eating insects. - BioScience 37 : $110-118$.

McLeod, J. M. 1970: The epidemiology of the Swaine jack-pine sawfly, Neodiprion swainei. — Forestry Chronicle 46: 126-133.

McNeil, S. \& Southwood, T. R. E. 1978: The role of nitrogen in the development of insect/plant relationships: 77-98. — In: Harborne, J. B. (ed.), Biochemical Aspects of Plant and Animal Coevolution. London, Academic. $452 \mathrm{pp}$.

Megahed, H. E. 2005: Effect of organic and inorganic fertilizers on the cowpea aphid (Aphis craccivora Koch.) infesting broad bean plants and the associated predators at Ismailia, Egypt. - Egyptian Journal of Agricultural Research 83: 639-648.

Nordström, F., Wahlgren, E. \& Ljungdahl, D. 1941: Svenska fjärilar. (Swedish Lepidoptera.) — Stockholm (Nordisk Familjeboks). 354 pp. [In Swedish.]

Pešlová, A. 2012: Possibilities to affecting oviposition preference, food selection and development of selected species of phytophagous insect by increased nitrogen nutrition of nutritive plants Betula pendula Roth. Ph.D. Thesis, Mendelu Brno. 119 pp. [In Czech.]

Pikul, J. L., Hammack, L. \& Riedell, W. E. 2005: Corn yield, nitrogen use, and corn rootworm infestation of rotations in the northern corn. - Agronomy Journal 97: 854-863.

Pitan, O. O. R., Odebiyi, J. A. \& Adeoye, G. O. 2000: Effects of phosphate fertilizer levels on cowpea podsucking bug populations and damage. - International Journal of Pest Management 46: 205-209.

Prestidge, R. A. 1982: The Influence of Nitrogenous Fertilizer on the Grassland Auchenorrhyncha (Homoptera). - Journal of Applied Ecology 19: 735-749.

Pronos, J., Merrill, L. \& Dahlsten, D. 1999: Insects and pathogens in a pollution-stressed forest. Oxidant Air Pollution Impacts in the Montane Forests of Southern California. A Case Study of the San Bernardino Mountains. - Ecological Studies 134: 317-337.

Rhoades, D. F. 1979: Evolution of plant chemical defense against herbivores: 3-54. - In: Rhozenthal, G. A. \& Janzen, D. N. (ed.), Herbivores: Their interactions with secondary plant metabolites. Academic Press, New York. 493 pp.

Rodin, L. E. \& Bazilevich, N. I. 1967: Production and 
Mineral Cycling in Terrestrial Vegetation. - London, Oliver and Boyd. 288 pp.

Salmah, M. R. C., Hassan, S. T. S., Hassan, A. A. \& Ali, A. B. 1998: Influence of physical and chemical factors on the larval abundance of Neurothemis tullia (Odonata: Libellulidae) in a rain led rice field. - Hydrobiologia 389: 193-202.

Shaw, G. G. \& Little, C. H. A. 1972: Effect of high urea fertilization of balsam fir trees on spruce budworm development: 589-597. — In: Rodriguez, J. G. (ed.), Insect and Mite Nutrition. Amsterdam, North Holland. $702 \mathrm{pp}$.

Schulz, K., Bonkowski, M. \& Scheu, S. 2008: Effects of Collembola and fertilizers on plant performance (Trticum aestivum) and aphid reproduction (Rhopalosiphum padi). — Basic and Applied Ecology 9: 182-188.

Smirnoff, W. A. \& Bernier, B. 1973: Increased mortality of Swaines jack pine sawfly and foliar concentrations after urea fertilization. - Canadian Journal of Forest Research 3: 112-121.

Srikanth, J., Salin, K. P., Easwaramoorthy, S. \& Kailasam,
C. 2002: Incidence of sugarcane shoot borer under different levels of weed competition. Crop Geometry, Intercropping and nutrient supply systems. - Sugar Technology 4: 149-152.

StatSoft, Inc. 2007: STATISTICA (software system for data analysis). Version 8.0. Available at www.statsoft.cz.

Šrámek, V., Novotný, R., Lomský, B., Maxa, M., Neuman, L. \& Fadrhonsová, V. 2009: Změny obsahů prvků v porostech smrku, buku, jeř́ábu a břízy v průběhu roku. (Seasonal change of element content in the forest stands of Norway spruce, European beech, mountain ash and white birch.) — Lesy České republiky, Hradec Králové. 109 pp. [In Czech.]

White, T. C. R. 1984: The abundance of invertebrate herbivores in relation to the availability of nitrogen in stressed food plants. - Oecologia (Berlin) 6: 90-105.

White, T. C. 1993: The inadequate environment - nitrogen and the abundance of animals. - Berlin, Heidelberg, New York, Springer-Verlag. 425 pp. 